Obtaining precollege student data, including attitudes, academic performance, past and expected engagement, and family and student characteristics, is important for institutions to gain a better understanding of the firstyear experience.

\title{
The Role of Precollege Data in Assessing and Understanding Student Engagement in College
}

\author{
James S. Cole, Marianne Kennedy, Michael Ben-Avie
}

Students do not enter college tabula rasa. They come with a variety of high school academic experiences, exposure to college information, and family socioeconomic and educational influences, all of which help shape expectations and attitudes of what it is like to be an enrolled college student. Research studies show that high school experiences, engagement, and academic achievement, as well as entering expectations and attitudes, are important predictors of student success. Therefore, to better understand first-year student engagement, it makes sense to consider the backgrounds and precollege characteristics of entering college students.

This chapter has two goals. The first is to clarify conceptually the relationship between precollege characteristics and high school engagement, first-year student engagement expectations, and subsequent first-year engagement and experience. The second is to provide examples of how academic affairs and student affairs use data on precollege student characteristics and student expectations to enhance student learning and personal development. We provide examples from institutions that have used the Beginning College Survey of Student Engagement (BCSSE), the precollege companion to the National Survey of Student Engagement (NSSE). 


\section{Student High School Experiences, Expectations, and Attitudes about College}

Many studies show that high school academic achievement and precollege behaviors and attributes are related to behaviors while in college, academic performance, and experiences in college. For instance, Cole and Kinzie (2007) found that 85 percent of the students who reported average grades of B in high school and expected overall grades of B in college actually earned overall grades of B by the end of their first year. In other words, high school grades and grade expectations predicted the first-year grades of many of these students. A number of other studies have also described the relationship of high school and college experiences and academic performance. Murtaugh, Burns, and Schuster (1999) reported that the higher the high school grade point average (GPA), the less likely the student will leave college before earning a degree. Bauer and Liang (2003) found that beyond the traditional predictors of college behaviors, such as high school GPA, standardized test scores, and gender, such personality traits as neuroticism were also important predictors of quality of effort in college, first-year college grades, and performance on a critical thinking exam. In a meta-analysis of 109 studies, Robbins and others (2004) found that socioeconomic status (SES), high school GPA, and ACT or SAT scores were all significant predictors of retention and first-year GPA. Astin and Lee (2003) found that precollege characteristics of hours spent studying in high school, academic ability, leadership ability, and developing a meaningful philosophy of life predict 61 percent of the variance in time spent studying in college. Given these results, these researchers questioned, "How much of the level of engagement observed among students at a given institution should be attributed to institutional policies and practices, and how much should be attributed to the characteristics of the students when they enroll?" (p. 670).

To the extent that an individual has a disposition to be engaged, we should expect a continuity of behavior and experiences between high school and college. Researchers (Ormrod, 2006; Schneider, 1996) define a disposition as an inclination to approach and think about a task and to behave in a particular way. At the same time, past behavior is not a perfect predictor of future behavior. The environment has an important inhibitory or facilitatory role in shaping behavior. From the social-cognitive view, this is referred to as reciprocal causation (Bandura, 1997). According to Bandura (1986), "People are neither driven by inner forces nor automatically shaped and controlled by external stimuli. Rather, human functioning is explained in terms of a model of triadic reciprocity in which behavior, cognitive and other personal factors, and environment events all operate as interacting determinants of each other" (p. 18). What this generally means is that student behaviors, such as interacting with faculty members, and personal factors, like motivation, and environment, such as the climate for learning inside and outside of class, are inextricably linked. In this view, high school engagement is not a disposition but the result of the reciprocal causation 
between the high school environment, personal characteristics, and the unfolding high school engagement itself over the course of the year. So the fact that high school engagement is often moderately predictive of college engagement does not necessarily represent a student's disposition; rather it represents the interaction of environment and personal characteristics that are often similar in college as in high school.

Of the many personal characteristics students have when they start college, some are for all practical purposes immutable, such as age, gender, and race. Other characteristics are open to influence, such as motivations, expectations, and aspirations, as a result of students interacting with the environment (Pintrich and Schunk, 2002). One such characteristic that has received attention of late are students' expectations regarding their first year of college (Miller, Bender, Schuh, and Associates, 2005).

\section{What Are Expectations?}

Expectations are the result of the interaction of our experiences with our anticipated environment (Olson, Roese, and Zanna, 1996). Expectations may also reflect what we expect to experience based on what others have experienced. In this sense, expectations are based not only on similar direct experiences but also on what we have learned from the experiences of others.

That expectations matter, the central premise for collecting data from students prior to starting fall semester classes, is also grounded in educational research. We have expectations for just about every situation we encounter, regardless of whether the situation is new or very familiar. Imagine, for example, your first day on campus as a first-year college student. Though you have never been a college student, you likely have many expectations about your first year of college. Your probably formed those expectations from your own personal high school experiences in and out of the classroom. For instance, you realize that your shyness to speak up in high school classes will likely still exist during your first year of college. You also believe that your interest in math and chemistry in high school will stay with you in college. Your expectations are formed from the information you glean from others. You create your expectations by talking to others who have attended college, from admissions materials you have received, campus visits, parents, a high school counselor, and others. Collectively all this information leads you to have expectations about your classroom experiences, your levels of engagement, social interactions, and out-of-class experiences during your first year of college.

These expectations also influence the upcoming choices you will make as your first year of college progresses. As Konings, Brand-Gruwel, van Merrienboer, and Broers (2008) claimed, "Expectations affect students' motivation, engagement, and investment of effort in learning" (p. 536). These authors describe three ways that expectations influence our perception, interpretation, and subsequent behavior. First, expectations bias perceptions by 
directing students' attention to choices that are consistent with the expectations themselves. Second, they bias students' interpretation of events to favor consistency with expectations rather than inconsistency. Third, they bias subsequent behaviors, in that students will tend to engage in a manner consistent with their expectations. In other words, "people tend to behave in such a way that their behavior optimally matches their expectations, and thus, they create what they expect, a phenomena known as a self-fulfilling prophecy" (Konings, et al., p. 536). The idea that student expectations have a confirmation bias that causes individuals to wittingly and unwittingly choose experiences that are likely to confirm their beliefs may explain some research that demonstrates the link joining behaviors in high school, expectations for college, and subsequent behaviors in college (Kirschner, Meester, Middelbeek, and Hermans, 1993; Nickerson, 1998). For instance, Konings, et al. (2008) found that students' expected dissatisfaction with school was highly correlated with their actual dissatisfaction after one and two years in college. Kuh, Gonyea, and Williams (2005) found that many student expectations, including expectations for writing, course learning, and student-faculty interaction, during the first year of college were significantly and moderately correlated with the students' actual experiences in college.

In contrast, many studies have reported that students' expectations are not well aligned with their experiences. The "freshman myth" describes expectations of incoming first-year students that exceed their actual behaviors in college. The result of this misalignment is often increased dissatisfaction with school, decreased academic and social integration, and overall decreased student performance (Braxton, Hossler, and Vesper, 1995; Howard, 2005). For instance, Baker, McNeil, and Siryk (1985) found that the expectations for social and academic adjustment of first-year students at two colleges significantly exceeded their actual reported social and academic adjustment. In a multi-institutional study of first-year students, Braxton, Hossler, and Vesper (1995) found that the more congruent experiences were, the more likely the student was to be satisfied. Level of congruence was also positively related to the likelihood of persisting to graduation.

Overall, research suggests a tendency for continuity between expectations and experiences and a tendency for students to overestimate their expectations in relation to their actual experiences. These results suggest that it is not enough to collect only student expectations data if we want to gain a better understanding of first-year engagement. In the context of reciprocal causation, we also need to know about the personal characteristics of the student and the role of the environment. We know that "expectations are always in flux and continuously revised in the face of new experiences" (Howard, 2005, p. 23). In the first-year student context, these new experiences are the interactions and engagement of the student in and out of the classroom during the course of his or her first year of college. These new 
experiences can also be thought of as the "environment" in Astin's inputenvironment-output (I-E-O) model (Astin, 1993).

According to Astin, in order to better understand the impact of college on students, we first need to assess the "inputs," or the relevant characteristics of students on entry to college. The "environment" is the educational experiences of the student: interaction with faculty, peers, and program policies that concern the student experience, for example. The "outcome," or impact, is the result of student inputs mixing with the environment. Because "students generally display a good deal of consistency in their level of academic and nonacademic engagement between high school and college" (Astin and Lee, 2003, p. 669), the I-E-O model helps us to better understand how inputs and environment relate to student outcomes.

The I-E-O model can also help us to make sense of student expectations. In this model, first-year-student expectations can be thought of as inputs in that they are the personal characteristics that students bring with them to campus. However, new experiences (environment) are also influenced by expectations, and therefore expectations continue to change as the year progresses. These environmental factors are largely the result of institutional policies and activities, campus climate, social life, and the classroom and academic environment created by faculty and staff. Therefore, to understand the impact of the environment on the output, we must first understand the inputs and how they relate to the environment.

A model of first-year engagement therefore should recognize the inputs as being both traitlike or stable (gender, race, SES) and situational (for example, high school engagement, college expectations, academic motivation). This parsing of inputs into two types is an important first step before using these variables as controls or covariates in any analysis. Failure to do so can result in the researcher's merely observing spurious correlations: when two variables are correlated as a result of a common cause (Pedhazur, 1997). For example, high school academic engagement is often moderately to highly correlated with first-year academic engagement (Astin and Lee, 2003). However, it may not be that high school engagement causes first-year engagement, but rather that they share some common causal agents. The students' high school engagement is likely "caused" by a mix of dispositions, gender, and other stable characteristics, along with the high school environment. These stable characteristics are also likely to be causal factors in first-year engagement. In other words, some of what causes first-year engagement are the same factors that cause high school engagement. Of course, the environment and other personal factors are different between high school and college. Thus, there is ambiguity as to how colleges affect student engagement on campuses. Expectations can clarify some of this conceptual ambiguity. Given how expectations are grounded in our experiences and influence our perceptions and behaviors, they provide a link between inputs and environment in a way that helps us understand the linkages between past experiences and the interaction with 
the current environment (Figure 4.1). The proposed model in Figure 4.1 reflects the reciprocal causation of person, environment, and behavior and indicates the I-E-O relationships. It also displays the continuous influence of stable, fixed characteristics of the individual on engagement across time and settings.

\section{Using Precollege Data to Improve the Student Experience}

As institutions of higher education move to expand assessment activities in order to improve students' learning and experiences and to comply with external accountability requirements, the need for more and better student data continues to increase. Assessment is undertaken not only in traditional academic programs, but in institution-wide programs such as general education and first-year experiences (Swing, 2004) and in cocurricular and student services areas (Gordon, Habley, and Associates, 2000). Collecting information from students before starting college, or during the first few weeks of classes, can be a useful source of information for many of these program-level and institution-level assessment efforts. For example, Tinto (1993) stressed the importance of gathering information on entering students in order to assess and understand retention systems adequately (Pascarella, 2001). Precollege information could help us understand the prior educational experiences of entering students as well as their attitudes toward and expectations for their first college year. Precollege assessment data provide important baseline information to document the effectiveness of program-level as well as institutional initiatives.

Many instruments are available to survey students at the beginning of their college experience. A comprehensive database and description of these instruments can be found on the Web site of the National Resource Center for the First-Experience and Students in Transition. Precollege assessments are typically administered during new student orientation or before fall classes begin. Students respond to a myriad of questions about their high school grades, test scores, courses completed, and other important academic indicators of high school success, as well as their involvement in extracurricular activities. Other surveys collect data on students' expectations for engagement during their first year of college, aspirations, motivations, and attitudes regarding academic preparedness. Some of these precollege surveys include the Cooperative Institutional Research Program (CIRP) Freshman Survey coordinated by the Higher Education Research Institute at the University of California at Los Angeles, which has been in use since 1966. More recent additions include the Retention Management System/College Student Inventory published by Noel-Levitz, the Beginning College Survey of Student Engagement (BCSSE), and the College Student Expectations Questionnaire (CSXQ). All of these surveys have companion surveys that can be administered later in the students' academic career. 


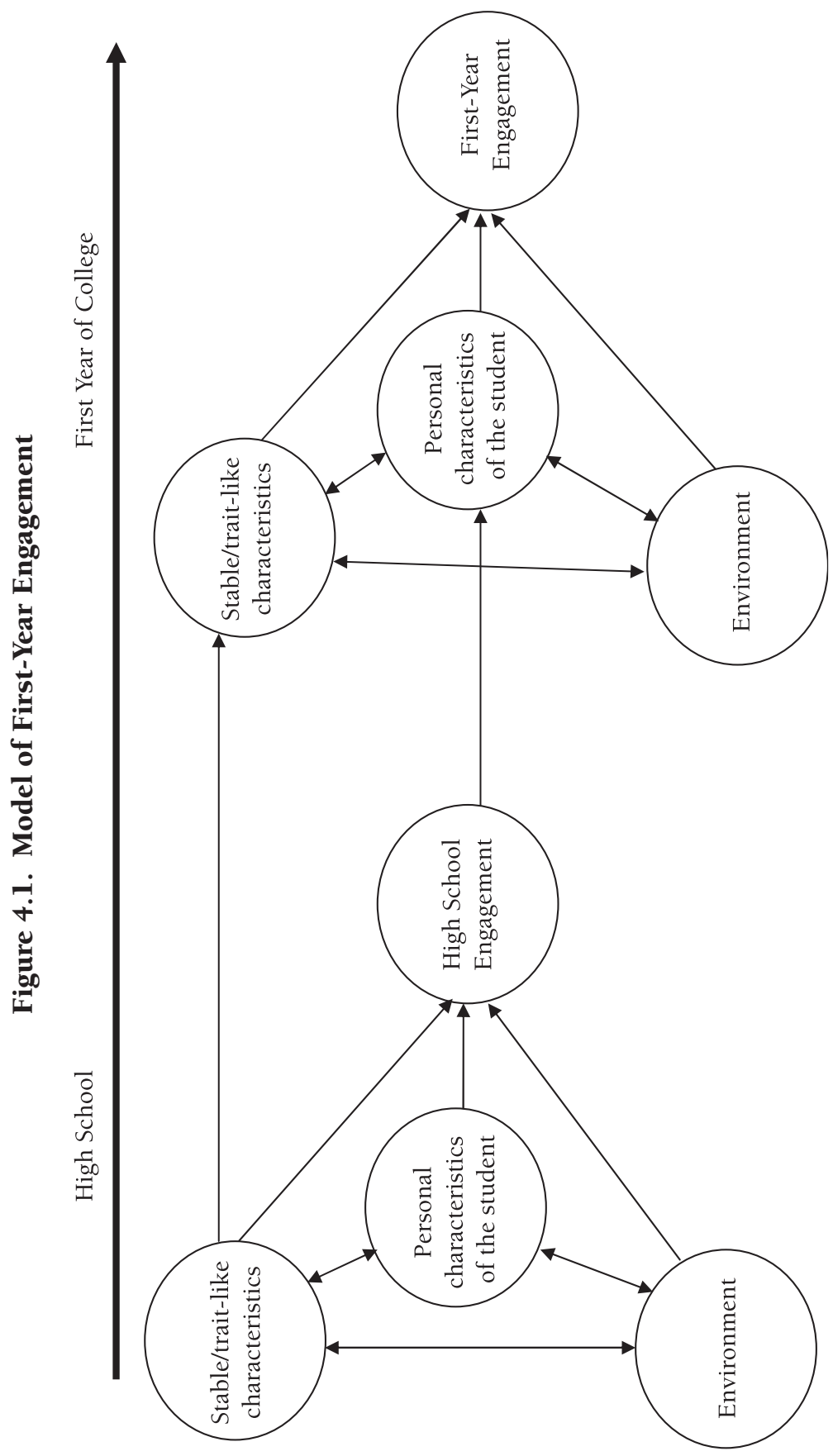

NEW DireCtIONS FOR INSTITUTIONAL RESEARCH • DOI: 10.1002/ir 
Information gleaned from precollege survey assessments, coupled with students' responses to subsequent surveys administered toward the end of the first year and their academic records, can provide institutions with information about mismatches between their expectations of college, perceptions of their actual experiences, and performance in the classroom. Precollege assessments can supply important information to inform planning processes and baseline data for panel and longitudinal studies. In this section, we discuss and illustrate some ways that these data may be useful to institutions.

Strategic Planning. An effective strategic plan reflects consideration of an objective and comprehensive look at the institution's current status. Most planning processes incorporate some variation of an environmental scan, including examination of internal and external forces affecting the university. During the strategic planning process, an institution would benefit from a realistic look at who its current students are, asking whether there are intentional ways in which the institution might want to change the composition of the student body. For example, an institution may seek to expose students to various forms and dimensions of human diversity. Assessing precollege educational experiences and expectations as one part of the environmental scanning process can yield enlightening information about the characteristics of entering students beyond the demographic information typically presented in admissions reports. Subsequent results from precollege assessments can also serve as a metric documenting whether new recruitment and enrollment management initiatives have achieved their targets.

First-Year Experience Programs. Many studies have documented the positive effects of first-year experience seminars on college persistence and academic achievement (Pascarella and Terenzini, 2005). In fact, most colleges and universities currently offer some variation of a first-year program to assist students in making a successful transition from high school to college. Meaningful measurement of the impact of first-year experience programs requires the collection of baseline data. Barefoot and others (2005) presented the case studies of thirteen institutions recognized as Institutions of Excellence in the design and implementation of first-year programs. One of the major conclusions of the study was that ongoing assessment was an essential component of excellent first-year programs. Several of the institutions profiled in the study used the precollege CIRP Freshman Survey to better understand who their students were and later used these data in combination with follow-up surveys such as the Your First College Year survey and locally designed instruments as part of program evaluation.

Swing (2004) asserted that students' introduction to assessment early in college may have an impact on the way they regard subsequent assessment activities. Providing feedback to participants about the results of the precollege assessment could have a positive impact on future assessment initiatives. That is, because colleges and universities ask first-year students to participate in other assessment activities during their time in college, engendering in them a feeling that they have a stake in these activities and 
that their survey results will be used to improve the experience of those who follow them may increase their motivation to complete future surveys. Precollege surveys are tools that can be helpful for both of these functions.

Faculty Development. To promote effective learning and employ effective instructional strategies, faculty members need to have an accurate picture of the students they are teaching. In a study of successful college teachers, Bain (2004) concluded that "part of being a good teacher (not all) is knowing that you always have something new to learn-not so much about teaching techniques but about these particular students at this particular time and their particular set of aspirations, confusions, misconceptions, and ignorance" (p. 174). Collecting precollege assessment data as a baseline provides an evidence-based description of the characteristics, perceptions, and expectations of students. Many schools use these data during newfaculty orientations and other faculty development activities in order to help faculty better understand the students they teach. For example, Kalamazoo College offers a workshop for faculty teaching a first-year seminar in which CIRP and other national and locally obtained data provide rich insights into the characteristics of their first-year students. The college used results from this survey to guide discussions about how best to respond to changing student needs and expectations (Barefoot and others, 2005).

Student Affairs Programs and Related Services. Astin (1993) pointed out the necessity of focusing on both the cognitive and the affective development of college students. In addition, extensive research (Kuh, 1995; Pascarella and Terenzini, 2005) has documented the benefits of cocurricular and extracurricular activities for college student development. This highlights the need for collaboration between those in student affairs and academic affairs. Precollege assessment can supply a common data set that informs both "sides of the house" about the characteristics of entering students. Student life and residence life professionals, disability resource officers, tutoring center staff, and registrars are potential consumers of these data.

Outreach and Admissions. Rigorous academic experiences before college are strongly correlated with success in college; thus, many have called for changes in high school curricula (Kuh, Kinzie, Buckley, Bridges, and Hayek, 2006). Tinto and Pusser (2006) made a number of suggestions to increase student success in college, including establishing linked P-16 systems, creating databases to follow students throughout their education, developing outreach programs for students from underrepresented groups, providing educational development for underprepared students, and "conducting early and continuous evaluation and assessment of student preparation for postsecondary access and success" (p. 20). A number of states have mandated increased alignment between K-12 standards and curricula and higher education to better match colleges' expectations. The report of the Secretary of Education's Commission on the Future of Higher Education, commonly referred to as the Spellings Commission, also recommended that all states provide incentives to institutions of higher education to work 
actively with $\mathrm{K}-12$ schools in this endeavor. Increased numbers of dualenrollment programs, early college, advanced placement courses, as well as other collaborative projects are likely to result from this emphasis. Precollege engagement data can be useful not only as a baseline for longitudinal study of the entering students, but in determining whether entering students' characteristics have changed over time. Precollege assessment results can serve as an important tool to set enrollment management goals as well as to ascertain whether those goals have been achieved.

Academic Advising. Researchers (Pascarella and Terenzini, 2005) suggest that academic advising plays a role in student persistence and graduation. Effective academic advising involves a teaching component; advisors not only help students decide which courses to take but should help students clarify their educational goals, identify knowledge and skills they will need, and help them reach a realistic understanding of their strengths and weaknesses (Erickson, Peters, and Strommer, 2006). BCSSE results made available to participating institutions include advising reports and individual summaries for each student (identified by student identification number) that can be printed out for advisement purposes. The College Student Expectations Questionnaire also supplies a student advisement reporting option that allows comparison of individual students' responses to those of the institution. These reports offer a wealth of information to start a conversation between advisor and advisee.

Merging Precollege Data with Other Sources. Using precollege assessment data to triangulate with other sources of data presents fuller information for data-based decision making and allows campuses to better understand the full experience of their students. These survey data, in combination with academic records of students, can serve as powerful documentation regarding the impact of various institutional programs.

\section{Institutional Examples}

Below are several examples of how institutions have used BCSSE data for advising, faculty development, strategic planning, and other activities.

Southern Connecticut State University. One such example of how an institution used precollege assessments for strategic planning, evaluation of first-year experience programs, faculty development, student affairs, and advising is at Southern Connecticut State University (SCSU).

SCSU was one of twenty-eight four-year colleges to participate in the original BCSSE pilot in 2004, and the university now has three years of BCSSE data. The campus community has engaged in an eighteen-month strategic planning process, during which leaders shared data from BCSSE, NSSE, and other sources with the steering committee and many of the work groups assigned to develop specific initiatives. SCSU's new mission statement clearly identifies student success as its top priority, and the vision statement describes the university as a student-centered institution. The campus identified a number of strategic initiatives dealing with student suc- 
cess, including development and implementation of a first-year experience (FYE) program, recruitment and retention of a larger percentage of highly qualified students, and improvement in the undergraduate advisement process.

Use of BCSSE data has been important to SCSU in the development and implementation of its pilot FYE program. SCSU has been following two cohorts of students who entered the university in fall 2004 and fall 2005. With BCSSE scores as the baseline measure, the cohorts consist of students who completed the NSSE during the second semester of their first year. The cohorts are a representative sample of the entering classes.

One of the findings from the study of the first two BCSSE-NSSE cohorts was that students seemed to continue to engage in behaviors that were successful for them in high school. However, these behaviors met only varying levels of success and often simply did not work well in college. For example, a large number of students who reported frequently asking questions in class and contributing to class discussions when they were in high school also reported doing the same in their first year of college. Conversely, students who tended not to ask questions or contribute to class discussions in high school did not do so during their first year at college. While the faculty knew this anecdotally, these data gave them confirmation that a targeted first-year program that would assist students in making a successful transition to college was absolutely crucial for SCSU students. The presentation of this evidence led to discussions about the optimal structure of an FYE program and ultimately to the pilot first-year-seminar program. The university also used BCSSE as a baseline in the subsequent program evaluation of the pilot seminar.

SCSU also used BCSSE and NSSE data for faculty development. Faculty were surprised and disturbed by some of the disconnects between students' expectations of college, as demonstrated by BCSSE results, and their actual first-year experience reported in NSSE results. For example, 59 percent of students in the BCSSE pilot expected to spend eleven to twenty-five hours per seven-day week preparing for class; in actuality, only 39 percent reported doing so in their first year of college. Although many faculty already suspected this, it was shocking to learn that 58 percent reported spending ten hours or less per week on studying.

Students' expectations and reality were more evenly matched in terms of the number of hours per week spent working for pay on or off campus. As part of SCSU's FYE Academy (training for faculty who were instructing seminars in the new pilot FYE program), faculty reviewed and discussed BCSSE (and NSSE) results, giving faculty participants more insight into the high school experiences and college expectations of first-year students. Program organizers asked a panel consisting of upper-class students who attended the discussion to comment on some of the findings. This resulted in a productive, revealing discussion between students and faculty, something that does not happen often enough. Faculty commented that they thought they knew their students, but seeing the data gave them new insight 
into understanding students' experiences and presented provocative challenges for pedagogy.

By understanding the experiences and expectations of entering students, student affairs staff can better tailor programs and services to the needs and interests of these students. In some cases, this means following up on findings through interviews or focus groups with students. For example, most entering SCSU students reported on the BCSSE that they expected to spend some time participating in cocurricular activities, yet more than half had not done so by the second semester of freshman year as indicated by NSSE results.

SCSU also creates a BCSSE advising report, "Anticipated Difficulties," that has been particularly informative for the advising process in the firstyear cohort study. For example, while most students anticipated having difficulty managing their time, students who expected to have difficulty keeping up with schoolwork completed the first year with lower GPAs than other students. In fact, all of the students with GPAs in the lowest quartile expected to have difficulty keeping up with schoolwork. SCSU plans to distribute BCSSE advisement summaries early in the fall semester to first-yearseminar instructors because they are also serving as academic advisors.

University of Wisconsin-Green Bay. The University of WisconsinGreen Bay (UWGB) plans to use precollege assessment data to support the need for its large and dynamic outreach program for middle and high school students called Phuture Phoenix (www.uwgb.edu/phuturephoenix/). The program relies on UWBG peer mentors to develop college awareness and increase educational aspirations in the Green Bay community.

In analyzing its BCSSE data, UWGB found that entering first-year students from the Green Bay Public Schools talked less often with school personnel about their college or career plans, were less certain about whether they will graduate from UWGB and about the highest degree they plan to obtain, and were less sure about what their major will be than all other entering first-year students at UWGB. The mentoring program can target these behaviors. Results from these items in future entering classes can help document the effectiveness of the mentoring program. Program leaders will also use summaries of BCSSE results in the training of student mentors around engagement-related themes, such as, "What does it mean to be a college student?" (with information about time use and important behaviors), and "How is college different from high school?" UWGB also prepares a report on BCSSE results for the campus on student expectations of college compared to their high school experiences and how they perceive college. It disseminates these results to chairpersons, deans, and offices directly involved with student registration and resources.

University of Maine at Farmington. University of Maine at Farmington (UMF) is another institution that uses precollege data effectively. By triangulating data from BCSSE, NSSE, and the Faculty Survey of Student Engagement (FSSE), UMF established a baseline for assessing the impact of 
its shift in 2006-2007 from a three-credit to a four-credit model for fullsemester courses. The results from the bundle of student engagement surveys will help UMF identify concerns that may emerge in implementing the four-credit model; administrators will assess the effectiveness of these efforts on the intended outcomes of enhancing academic rigor, raising performance expectations, and involving students in more writing and research.

Brigham Young University. Brigham Young University (BYU) compares students' descriptions of their academic experiences from their NSSE results with the expectations they described prior to starting classes on their BCSSE results. FSSE responses make it possible to examine faculty perceptions alongside student experiences. BYU's Faculty Center will report these findings during new-faculty training and internal workshops.

Illinois State University. Illinois State University (ISU) plans to draw on BCSSE, NSSE, and FSSE findings to guide campus conversations among current students, prospective students, faculty, student affairs personnel, and other key stakeholders about the differences between the nature of student engagement in high school and what is expected at the university. By integrating faculty perceptions of student engagement into the mix, they hope to understand how engaged learning can be further enhanced through current campus initiatives, such as civic and political engagement, the first-year experience, general education outcomes, and partnerships for student learning. The university will also use the combined data to assess the impact of these and related efforts to increase the quality of the undergraduate experience.

\section{Conclusion}

Precollege student engagement and expectations data are instructive, as illustrated by the examples in this chapter. Specifically, precollege data can be profitably used in these ways:

- Understanding student backgrounds, experiences, and expectations so that institutions can minimize unmet expectations and increase student engagement, learning, satisfaction, and persistence

- Contextualizing strategic plans with entering student characteristics that are relevant for designing effective teaching and learning practices

- Designing and evaluating first-year programs to more effectively align them with student background characteristics and expectations

- Helping faculty better understand who their students are in order to modify curriculum materials and teaching practices

- Informing advisors about students' prior academic and extracurricular experiences, academic preparation, attitudes, and expectations to best advise the student

- Merging with other data sources to provide a richer understanding of the first-year experience 


\section{References}

Astin, A. What Matters in College? Four Critical Years Revisited. San Francisco: JosseyBass, 1993.

Astin, A. W., and Lee, J. J. "How Risky Are One-Shot Cross-Sectional Assessments of Undergraduate Students?" Research in Higher Education, 2003, 44(6), 657-672.

Bain, K. What the Best College Teachers Do. Cambridge, Mass.: Harvard University Press, 2004.

Baker, R. W., McNeil, O. V., and Siryk, B. "Expectations and Reality in Freshman Adjustment to College." Journal of Counseling Psychology, 1985, 32(1), 94-103.

Bandura, A. Social Foundations of Thought and Action: A Social Cognitive Theory. Upper Saddle River, N.J.: Prentice Hall, 1986.

Bandura, A. Self-Efficacy: The Exercise of Control. New York: Freeman, 1997.

Barefoot, B. O., and others. Achieving and Sustaining Institutional Excellence for the First Year of College. San Francisco: Jossey-Bass, 2005.

Bauer K. W., and Liang, Q. "The Effect of Personality and Precollege Characteristics on First-Year Activities and Academic Performance." Journal of College Student Development, 2003, 44(3), 277-290.

Braxton, J., Hossler, D., and Vesper, N. "Incorporating College Choice Constructs into Tinto's Model of Student Departure: Fulfillment of Expectations for Institutional Traits and Student Withdrawal Plans." Research in Higher Education, 1995, 36(5), 595-612.

Cole, J. S., and Kinzie, J. "Precollege Student Expectations and Attitudes Regarding Their First-Year of College." Paper presented at the Annual Meeting of the Southern Association for Institutional Research, Little Rock, Ark., Oct. 8, 2007.

Erickson, B. L., Peters, C. B., and Strommer, D. W. Teaching First-Year College Students. San Francisco: Jossey-Bass, 2006.

Gordon, V. N., Habley, W. R., and Associates. Academic Advising: A Comprehensive Handbook. San Francisco: Jossey-Bass, 2000.

Howard, J. "Why Should We Care About Student Expectations?" In T. E. Miller, B. E. Bender, J. H. Schuh, and Associates (eds.), Promoting Reasonable Expectations: Aligning Student Views of the College Experience. San Francisco: Jossey-Bass, 2005.

Kirschner, P., Meester, M., Middelbeek, E., and Hermans, H. "Agreement Between Student Expectations, Experiences, and Actual Objectives of Practicals in the Natural Sciences at the Open University of the Netherlands." International Journal of Science Education, 1993, 15(2), 175-197.

Konings, K. D., Brand-Gruwel, S., van Merrienboer, J.J.G., and Broers, N. J. "Does a New Learning Environment Come Up to Students' Expectations? A Longitudinal Study." Journal of Educational Psychology, 2008, 100(3), 535-548.

Kuh, G. D., Gonyea, R. M., and Williams, J. M. "What Students Expect from College and What They Get." In T. E. Miller, B. E. Bender, J. H. Schuh, and Associates (eds.), Promoting Reasonable Expectations: Aligning Student Views of the College Experience. San Francisco: Jossey-Bass, 2005.

Kuh, G. D. "The Other Curriculum: Out-of-Class Experiences Associated with Student Learning and Personal Development." Journal of Higher Education, 1995, 66(2), 123-155.

Kuh, G. D., Kinzie, J., Buckley, J., Bridges, B., and Hayek, J. C. "What Matters to Student Success: A Review of the Literature." Bloomington: Indiana University Center for Postsecondary Research, 2006.

Miller, T. E., Bender, B. E., Schuh, J. H., and Associates (eds.). Promoting Reasonable Expectations: Aligning Student Views of the College Experience. San Francisco: Jossey-Bass, 2005.

Murtaugh, P. A., Burns, L. D., and Schuster, J. "Predicting the Retention of University Students." Research in Higher Education, 1999, 40(3), 355-371.

Nickerson, R. S. "Confirmation Bias: A Ubiquitous Phenomenon in Many Guises." Review of General Psychology, 1998, 2(2), 175-220. 
Olson, J. M., Roese, N. J., and Zanna, M. P. "Expectancies." In E. T. Higgins and A. W. Kruglanski (eds.), Social Psychology: Handbook of Basic Principles. New York: Guilford Press, 1996.

Ormrod, J. E. Educational Psychology: Developing Learners. (5th ed.) Upper Saddle River, N.J.: Pearson, 2006.

Pascarella, E. T. "Using Student Self-Reported Gains to Estimate College Impact: A Cautionary Tale." Journal of College Student Development, 2001, 42(5), 488-492.

Pascarella, E. T., and Terenzini, P. T. How College Affects Students. San Francisco: JosseyBass, 2005.

Pedhazur, E. J. Multiple Regression in Behavioral Research: Explanation and Prediction. (3rd ed.) Fort Worth, Tex.: Harcourt Brace, 1997.

Pintrich, P. R., and Schunk, D. H. Motivation in Education: Theory, Research, and Applications. (2nd ed.) Upper Saddle River, N.J.: Pearson, 2002.

Robbins, S. B., and others. "Do Psychosocial and Study Skill Factors Predict College Outcomes? A Meta-Analysis." Psychological Bulletin, 2004, 130(2), 216-288.

Schneider, D. J. "Attribution and Social Cognition." In A. M. Colman (ed.), Companion Encyclopedia of Psychology. London: Routledge, 1996.

Swing, R. "What's So Special About Assessment in the First Year of College?" Assessment Update, 2004, 16(2), 1-4.

Tinto, V. Leaving College: Rethinking the Causes and Cures of Student Attrition. (2nd ed.) Chicago: University of Chicago Press, 1993.

Tinto, V., and Pusser, B. "Moving from Theory to Action: Building a Model of Institutional Action for Student Success." Paper presented at the National Symposium on Postsecondary Student Success, Washington, D.C., Nov. 2006.

JAMES S. COLE is program manager for the Beginning College Survey of Student Engagement and assistant scientist at the Center for Postsecondary Research at Indiana University-Bloomington.

MARIANNE KENNEDY is associate vice president for assessment, planning, and academic programs at Southern Connecticut State University.

MICHAEL BEN-AVIE is associate coordinator of assessment and planning at Southern Connecticut State University 